\title{
IAMJ
}

INTERNATIONAL

AYURVEDIC

MEDICAL JOURNAL

\section{PATHOGENESIS AND MANAGEMENT OF COVID-19 FROM THE PERSPECTIVE OF AYURVEDA}

\section{Pathak Reetika $^{1 *}$, Inchulkar S. R. ${ }^{2}$, Bhagat Sangeeta ${ }^{3}$}

${ }^{1}$ MD Scholar, Department. of Agad Tantra Evam Vidhi Ayurved, Shri N.P.A. Govt. Ayurved College, Raipur, Chhattisgarh, India

2Professor \& HOD, Department. of Agad Tantra Evam Vidhi Ayurved, Shri N.P.A Govt. Ayurvedic College, Raipur, Chhattisgarh, India

${ }^{3}$ Lecturer, Department. of Agad Tantra Evam Vidhi Ayurved, Shri N.P.A Govt. Ayurvedic College, Raipur, Chhattisgarh, India

\section{Corresponding Author:pathakreetika922@gmail.com}

\section{https://doi.org/10.46607/iamj4109092021}

(Published Online: September 2021)

Open Access

(C) International Ayurvedic Medical Journal, India 2021

Article Received:26/08//2021 - Peer Reviewed:04/2021 - Accepted for Publication:05/09/2021

\section{Check for updates}

\section{ABSTRACT}

Today the whole world is going through an epidemic, which has been declared as a Corona pandemic. From village to city, from country to abroad, from elders to children, from illiterate to scientist, no one is untouched by its wrath. It is spreading from person to person through infection. The whole world is fighting this Corona virus and is engaged in getting rid of it. The entire medical system of the world, the medical community and other public sectors are playing their role as Covid-Warriors. Inhalation of infectious aerosols and close contact are the main routes of Covid-19 transmission. Proper prevention \& management to stop or slow the spread of a contagious disease. Ayurveda is also engaged in treating it with its original purpose. Ayurveda is a science of life, which deals with comfort and discomfort physiological and pathological aspects of life. The first principle of Ayurveda is to protect the health of the healthy, in which Ayurveda proclaims the ethics, it paves the way for a healthy lifestyle while eradicating diseases its second principle, in which Ayurveda describes its medical principles. Following a routine with a balanced diet is extremely important during the Corona period. A healthy diet \& lifestyle is very 
important before, during \& after an infection. People should resort to Panchkarma therapy and also to rejuvenation therapy with medicines that increase the strength of the body. Yoga helps a significant role in the psychosocial care and rehabilitation of Covid-19 in quarantine and isolation.

Keywords: Ayurveda, Covid-19, Health, Panchakarma, Yoga.

\section{INTRODUCTION}

A healthy man is one whose soul-mind senses are happy, and whose Dosha, Dhatu, Mala and Agni are in equilibrium. This is a specific type of description in which a healthy body and healthy mind together form a healthy 'Purusha (man). Everyone's routine, which is individualistic dependent, lockdown status has changed it, even the busiest lifestyle has kept us sick in the past, nature once gives everyone the opportunity for the right changes, about lockdown time is the right chance, in which we can achieve the love of nature by making healthy changes in lifestyle by creating a healthy environment with family. We have to start from our home and ourselves to make India even world healthy and prosperous. You can use this time as an irregular routine or healthy wake-up, eat healthily and be happy, it is in your hand. Therefore, the aim is to study Covid-19 in the context of Ayurveda.

\section{AIM \& OBJECTIVE}

To study Covid-19 in the context of Ayurved.

\section{MATERIAL AND METHODS}

Ayurvedic Classical texts were used as a source material like Brahatraiye, Authorized Laguhtraiye, Ayurvedic Teekas, Nighantu etc.

Pathogenesis - Exciting cause of both the exogenous and innate disorders is unwholesome contact with the sense objects, intellectual error, and consequence. Maharshi Charak says - 'Dwayostukhaluaagantunijyopreranasaatmyindriyarthsamyogpragyaparaadhparinaam cha iti.' [1]

\section{Samprapti Chakra (An Ayurvedic view)}

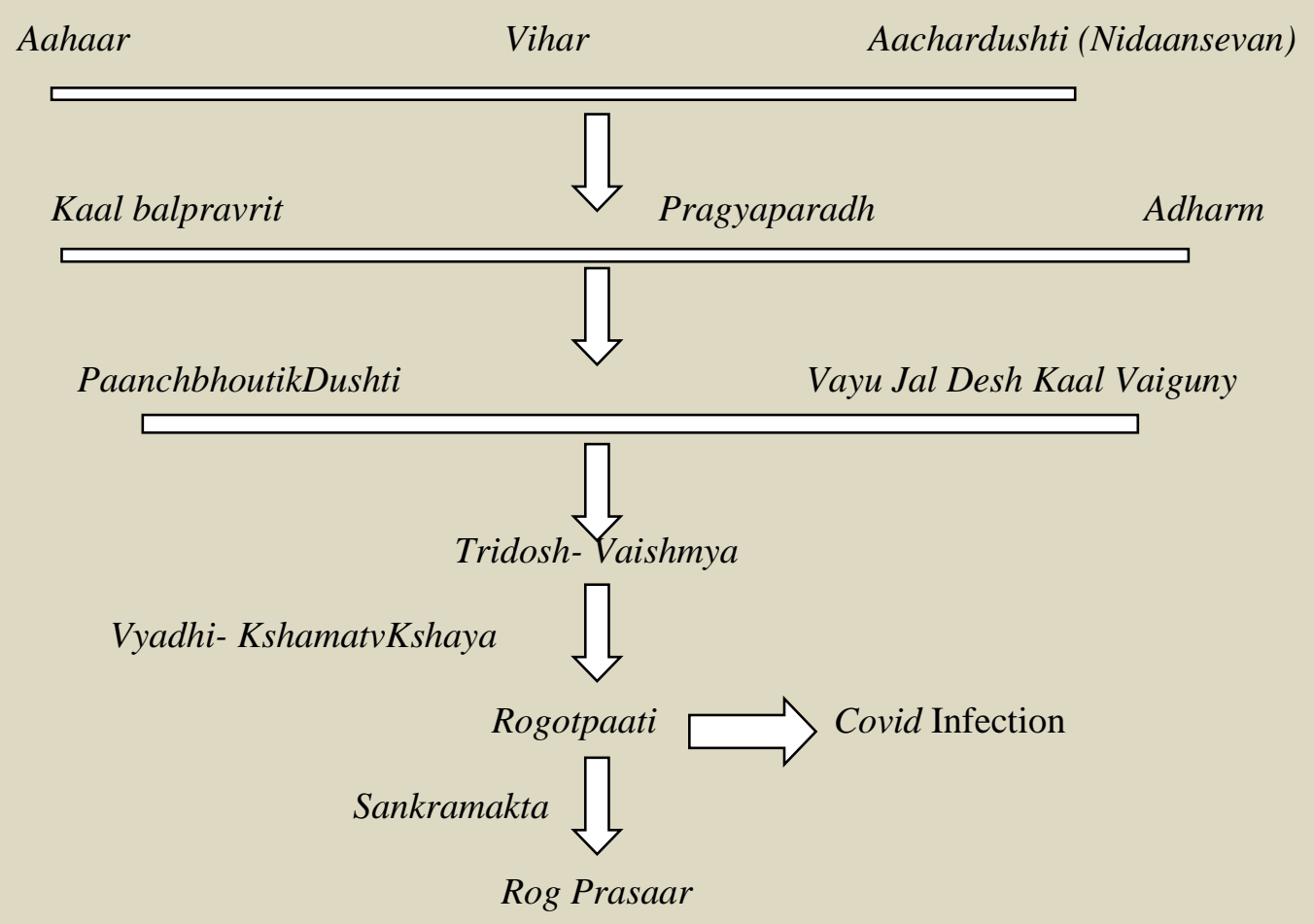




\section{Covid Management protocol in Ayurveda-}

- Follow government order - Good knowledge of the instructions of the authorities and their implementation is the cause for prevention and alleviation of diseases. 'Sanshepatakriyoyogonidanamparivarjnam. ${ }^{[2]}$

- Stay home-Stay safe - To avoid the Corona epidemic that we are all fighting today, the government has said people stay at home. Maharshi Charak has said where you have all your security, you have to live there, and that's your house.

'Sadvrattaanuvratischaprashmoguptaatmana,

Hitamjanpadanaam cha shivanaamupsevnam. ${ }^{\text {,3] }}$

- Hand-Sanitization - Maharshi Charak described right conducts likes hands must be washed before meals. 'Na prakshalitpani. ${ }^{\text {'4] }}$

- Social-distancing - Ayurveda Samhitas has already described the social distance; one should walk having to look six feet forward that we are talking about today Covid-19. Maharshi Charak says- 'Yugmatradrakvicharet. ${ }^{\text {[5] }}$

- Sneezing-Rule (Wear a Mask) - One should not sneeze without covering his mouth. ' $\mathrm{Na}$ Asamvratmukhakuryaat. ${ }^{[6]}$

- Avoid Weak Zone and Bed Habits - A smoky, infected atmosphere directly irritates the upper respiratory passages and increases mortality from pulmonary diseases. Do not adopt any work that is affecting our health or leave it quickly, like alcohol, cigarettes etc.

\section{Purpose of treatment -}

The objective of this compendium is the achievement of Dhatusamya (Equilibrium of sustaining and nourishing factors i.e. body constituents) Maharshi Charak says 'Dhatu samya kriya chokta tanka aasyaprayojnam. ${ }^{[7]}$

\section{Home remedy-}

Staying at home and eating unhealthy things, cholesterol label is increasing, so in this kind of situation use kitchen material as a medicine. Mostly because of staying at home, eating unhealthily, sleeping at the wrong time, and waking up late at night, due to which our metabolic system and body shape-size disturb, and mental stress have also increased, during this time, the items available in the kitchen can be used as good Ayurveda medicine against Corona epidemic.

- Hingu - Hingu is regarded to be effective in the treatment Vata and Kapha Dosha. It is pungent, hot, appetizing, light, and alleviates colicky pain. 'Vaatsleshmavibandhaghanamkatu-

shnamdeepanamlaghu, Hingushoolprashmanamvidyaatpaachanrochnam. ${ }^{[8]}$

- Maricha - Maricha is not very hot, is an aphrodisiac, light, and appetizing is depletive and desiccating. It is effective in treating Kapha and Vata. Its insecticidal activity is reported. 'Cheditwatshoshantwachadeepnamkafavaatjita. ${ }^{,[9]}$

- Pippali-Ghrit prepared with Pippali and milk wil be useful. Pippali, Amalaki and Sunthi are taken with honey and sugar in SwasaRoga. 'Yogvaahinitukhalubhavanti. ${ }^{\prime}[10]$

- UshnajalaDalchini, Haridra, Yavani, Jeeraka, Aardraka, Shunthi, Tila- Helps digestion, cleanses the urinary bladder, relieves in Vaat, Kapha, fever of recent origin, cold, cough, rhinitis, dyspnoea and others. Astang Hridaykaar says about hot water 'Deepanampachnamkanthyamlaghuushnamvastishodhnam, kaasaaamapeenasswasaparshwaurukshu cha shasyate. '[11]

- Milk - Promotes long life, anti-ageing rejuvenating, strengthening, relieves exhaustion, toxicity, dyspnoea, chronic fever and more. Astang Hridaykaar says

'Gavyamtujeevneeyamrasayanam. ${ }^{\text {'[12] }}$

Medicine should have multi-functional properties such as Tridosha Shaamak, anti-worm, skin protective, immune booster, more effective in diseases

- Neem oil - is slightly hot in potency, bitter, antimicrobial, useful in skincare. Astang Hridaykaar says 'Naaatiushnamtiktamkramikushthakafapranut. ${ }^{\text {[13] }}$

- Dashmool, Triphala, Trikatu, Yashtimadhu, Guggulu, Asvagandha, etc., use their Yogas (Groups) in medicine. You should drink the juice of Amla, Aloe Vera, Giloyetc. regularly. 
- Nashya - It is useful in headache, heaviness, worm infestation, skin diseases, and rhinitis. Astang Hridaykaar says about Nasya 'Shophagandakramigranthikushthaapasmaa rpeenase. ${ }^{[14]}$

- Gandusha (Mouth gargles) - Relieve respiratory tract problems.

- Yoga-Corona effect has two places where they reside Body and Mind. Therefore, good health is the one in which the mind is healthy along with the body, and there is nothing better than Yoga to upgrade mental health.

- Bath- At this time, Covid warriors and all the people are covered with the whole body, due to which the body gets stiff, but it is necessary to bath twice a day with clean water, in addition to other properties bathing is relieved tiredness, eliminate sweat and specially Rakta-Prasadak. (Blood Circulation flow) Acharya Susurt says 'Nidradaahashrama haram swedakandutrishapaham, Raktprasadanamchapisnanamagneshadeepnam. ${ }^{\text {[15] }}$

- Diet- Person should take a suitable meal in limited quantity, after digestion of a previous meal. Manda, Peya, Vilepi, are more easily digestible in their preceding order of enumeration. Aacharyas says 'Jeernehitammitamchadyaana. ${ }^{,[16]}$ Corona epidemic has been accepted as an exogenous epidemic and a balanced diet is necessary to prevent this exogenous disease. Maharshi Charak says about Aahar- 'ajataanaamvikaraanaamanutpattikaram cha yat ${ }^{\text {'[17] }}$

- Immunity - The ability to fight against diseases and prevent diseases from occurring again is immunity, and the Ayurveda Aacharyas have called it Vyadhi-kshamatv (Immunity). Aacharya Charak says 'Baladhisthanaarogyam. '[18]

- Aachar Rasayana- In Ayurveda, 'Aachar' is described as a Rasayana. Aachar Rasayana aimed in providing excellent mental, physical, social and spiritual health without having any medicine. 'Dharm shastra param vidyatnaramnityamrasayanam'.[19]

\section{DISCUSSION}

Co-operation in government health orders should be our duty. As the citizens of India, we all have the responsibility to protect ourselves, protect our loved ones and help make the country healthy and prosperous. Not the last but the essential quality. To know the health parameters of other countries it is necessary to have a good relationship with each other. In case of emergency, we can cooperate mutually. Can prevent a deadly pandemic from spreading in our country from the point of view of health, as seen now Corona virus infection.

The inadequate, improper and excess association of these three things Kala (Season), Arth (Senses) and Karma (Activities) is the main reason for the occurrence of disease, while their proper association is the main cause of health. Forsaking the intellectual errors, Pacification of sense organs, memory, sound knowledge of the place, time and self, following the code of good conduct, the wise should do quite early what he thinks wholesome for himself. 'Tyagahpragyaparadhanamindriyopshama smriti, Deshkaalatmvigyanamsadvratashyanuvartnam. ${ }^{[20]}$

We have become so busy in today's puzzling life that there is no time for ourselves, and in such a situation it is very difficult to follow the rules of nature. But Ayurveda says that a wise person should be cautious in duties relating to his own body. Maharshi Charak says 'Swasharirasyamedhavikratyeshwavahitobhavet. ${ }^{[21]}$ Ayurveda considers a healthy person both from body and mind. Therefore, be health conscious, save the environment, renunciation of iniquity, observance of religion, should be happy, recognize your strengths and adopt Ayurveda in life.

\section{CONCLUSION}

To maintain health, body and mind both are necessary to be healthy. To maintain health in corona pandemic, diet, lifestyle, Humanity, harmony with nature, behaviour, time management, proper sleep, and health awareness is an important factor. At present, it is most important to be alert and aware of health. Regular exercise, meditation, yoga, and qualitative diet on time, good and supportive friends; balanced 
use of electronics, renunciation of bad habits keep us healthy. In this time of crisis, all departments are giving their support with full dedication as Covid warriors. Therefore, being a doctor, everybody looks at us with confidence and hope. When it comes to the use of diet $\&$ lifestyle with prevention $\&$ cure, so the scope and responsibility of Ayurveda increase even more. The final victory will happen only when along with us the whole world will be healthy and happy.

\section{REFERENCES}

1. Dr Brahmanand Tripathi, Hindi commentary, CharakSamhita, Sutrasthan, Maharoga Adhyaya, 20/5, Reprint edition 2006, Chaukhamba Surbharti Prakasan Varanasi, Page; 387

2. KavirajAmbikadutta Shastri, Hindi commentary, Susruta Samhita, Part ${ }^{2 n d}$, Uttar tantra, Aoupadravik Adhyaya, 1/25, Reprint edition 2010, Chaukhambha Sanskrit Sansthan Varanasi, Page; 14

3. Dr Brahmanand Tripathi, Hindi commentary, Charaka Samhita Vimansthan, Janpadodhwanshneey Adhyaya, 3/15-16, Reprint edition 2006, Chaukhamba SurbhartiPrakasan Varanasi,Page; 679

4. Dr Brahmanand Tripathi, Hindi commentary, Charaka Samhita Sutrasthan, Indriya-Upkramneey Adhyaya, 8/20, Reprint edition 2006, Chaukhamba Surbharti Prakasan Varanasi, Page; 200

5. Dr Brahmanand Tripathi, Hindi commentary, Charaka Samhita Sutrasthan, Indriya-Upkramneey Adhyaya, 8/18, Reprint edition 2006, Chaukhamba Surbharti Prakasan Varanasi, Page; 197

6. Dr Brahmanand Tripathi, Hindi commentary, Astanga hrdayam Sutrasthan, Dincharya Adhyaya, 2/35, Reprint edition 2012, Chaukhamba Sanskrit Pratishthan Delhi, Page; 37.

7. Dr Brahmanand Tripathi, Hindi commentary, Charaka Samhita Sutrasthan, Deerghjeevteeya Adhyaya, 1/53, Reprint edition 2006, Chaukhamba Surbharti Prakasan Varanasi, Page; 25

8. Dr Brahmanand Tripathi, Hindi commentary, Charaka Samhita Sutrasthan, Annapaanvidhi Adhyaya, 27/299, Reprint edition 2006, Chaukhamba Surbharti Prakasan Varanasi,Page; 537

9. Dr Brahmanand Tripathi, Hindi commentary, Charaka Samhita Sutrasthan, Annapaanvidhi Adhyaya, 27/298, Reprint edition 2006, Chaukhamba Surbharti Prakasan Varanasi, Page; 537

10. Dr. Brahmanand Tripathi, Hindi commentary, Charaka Samhita Vimansthan, Ras-Viman Adhyaya, 1/16, Reprint edition 2006, Chaukhamba Surbharti Prakasan Varanasi, Page; 660

11. Dr Brahmanand Tripathi, Hindi commentary, Astanga hrdayam Sutrasthan,Drav-dravyvigyaneey Adhyaya,
5/16-17, Reprint edition 2012, Chaukhamba Sanskrit Pratishthan Delhi, Page; 68.

12. Dr Brahmanand Tripathi, Hindi commentary, Astanga hrdayam Sutrasthan, Drav-dravyvigyaneey Adhyaya, 5/21, Reprint edition 2012, Chaukhamba Sanskrit Pratishthan Delhi, Page; 69.

13. Dr Brahmanand Tripathi, Hindi commentary, Astanga hrdayam Sutrasthan, Drav-dravyvigyaneey Adhyaya, 5/60, Reprint edition 2012, Chaukhamba Sanskrit Pratishthan Delhi, Page; 78.

14. Dr Brahmanand Tripathi, Hindi commentary, Astanga hrdayam Sutrasthan, Nasyavidhi Adhyaya Adhyaya, 20/3, Reprint edition 2012, Chaukhamba Sanskrit Pratishthan Delhi, Page; 244.

15. KavirajAmbikadutta Shastri, Hindi commentary, Susruta Samhita, Part ${ }^{1 \mathrm{st}}$, Chikitsasthan, AnagatBadhapratishedh Adhyaya, 24/57-58, Reprint edition 2010, Chaukhambha Sanskrit Sansthan Varanasi, Page; 135

16. Dr Brahmanand Tripathi, Hindi commentary, Astanga hrdayam Sutrasthan, Dincharya Adhyaya Adhyaya, 2/19, Reprint edition 2012, Chaukhamba Sanskrit Pratishthan Delhi, Page; 33.

17. Dr Brahmanand Tripathi, Hindi commentary, Charaka Samhita Sutrasthan, Maatra-Shiteey Adhyaya, 5/13, Reprint edition 2006, Chaukhamba Surbharti Prakasan Varanasi, Page; 108

18. Dr Brahmanand Tripathi, Hindi commentary, Charaka Samhita Chikitsasthan, Jwar Chikitsa Adhyaya, 3/142, Reprint edition 2007, Chaukhamba Surbharti Prakasan Varanasi, Page; 164

19. Dr Brahmanand Tripathi Editor Caraka-Samhita, Chikitsasthan, Ayurved Samuthaneey- Adhyaya, 1/4/34, Reprint edition 2007, Chaukhamba Surbharti Prakashan Varanasi, Page; 69

20. Dr Brahmanand Tripathi, Hindi commentary, Charaka Samhita Sutrasthan, Na-Vegaandharneey Adhyaya, 7/53, Reprint edition 2006, Chaukhamba Surbharti Prakasan Varanasi, Page; 185

21. Dr Brahmanand Tripathi, Hindi commentary, Charaka Samhita Sutrasthan, Maatra-Shiteey Adhyaya, 5/103, Reprint edition 2006, Chaukhamba Surbharti Prakasan Varanasi, Page; 141

\section{Source of Support: Nil \\ Conflict of Interest: None Declared}

How to cite this URL: Pathak Reetika et al: Pathogenesis And Management Of Covid-19 From The Perspective Of Ayurveda. International Ayurvedic Medical Journal \{online\} 2021 \{cited September 2021\} Available from: http://www.iamj.in/posts/images/upload/2191_2195.pdf 